\title{
The church and the secular: The effect of the post-secular on Christianity
}

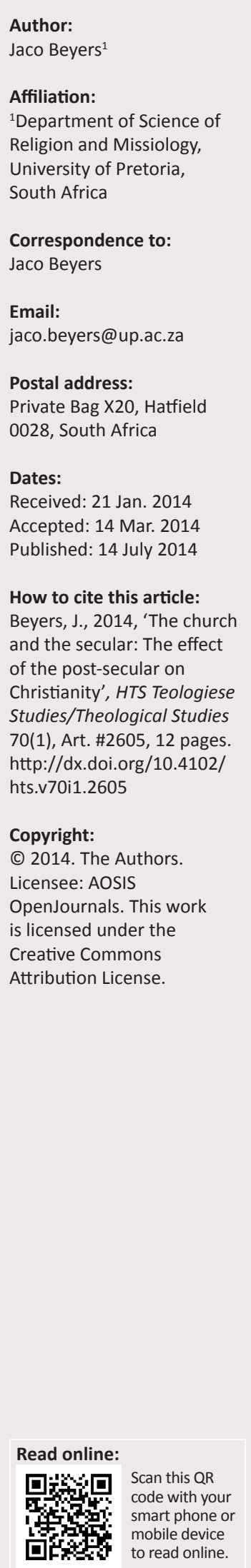

Paradigms determine relationships. During the Enlightenment period Emile Durkheim proposed a relationship between the sacred and the profane. Religion, which is concerned with the sacred, was defined in terms of being different from the profane. The profane came to denote the secular. The organic character of religion caused some scholars to predict the end of the church at the hand of modernisation and rationalisation. Some scholars instead envisaged a new form and function of the church. Some scholars anticipated the growth of Christianity. Reality shows that Christianity has not died out but seems to be growing. The new era we are currently in (identified as the postmodern) has been described as the post-secular age where a process of re-sacralisation takes place. How will the post-secular influence the church? What will the relationship between the church and the secular be like under a new paradigm? This article suggests that within a postmodern paradigm, the post-secular will emphasise the place of the individual in the church. Fragmentation of society will also be the result of the postsecular. Religiosity in future will have to contend with fundamentalism and civil religion.

\section{Introduction}

\section{Problem}

It is clear that a gradual decline in expression of belief and religious practices characterised the past century. The normative status of Christianity that characterised earlier centuries has been lost. Recently there seems to be a worldwide growing religious awareness of some sort, impacting on the church. What brought about this change? What effect did the process of secularisation have on the church, but more important, how does the post-secular effect the church? What can be predicted as to the relationship between the church and the secular in future?

The church has an organic nature; interacting with its surroundings. There are constant reciprocal influences and interactions between the church and its surrounding contexts. This causes the form of the church to constantly change as contexts determine. Paradigms influence the relationship between the secular and the sacred. Internal as well as external factors influence the forms of expression of the church. Theologians are constantly analysing and reconstructing the face of the church in light of the paradigm and context of the current time. This has led to numerous declarations on the future of the church: religion will be relinquished to the private sphere (Durkheim). Some indicated that the social function of the church will change (Weber). Some declared that the church will in future totally die out (Berger; Bruce). Some indicated that religion will eventually grow (Berger), whereas some emphasised that this growth will only be in the private sector (Luckmann). Others indicated that this growth will be amongst the poor and destitute (Norris \& Inglehart). The question facing theologians today is what the anticipated face of the church will look like in future? The actual question ought to be what tendencies can be identified which will influence the future face of the church?

\section{Methods}

This article attempts to indicate through the use of document analysis (literature research), discourse analysis (how relationships are created by words) and conceptual analysis (discussing abstract concepts) what the future face of the church might look like. As this study includes a particular historic overview of the development of the relationship between the church and the secular, a synchronic as well as a diachronic perspective will be presented. A linear understanding of history does not necessarily imply an evolutionistic progressive development of the relationship between the church and the secular.

\section{Theoretical framework}

The scientific way in which questions are asked and answered is determined by paradigms. Broad consensus exists as to the pre-modern-modern-postmodern division of history (King 
2009:46). The parallel division of pre-secular-secular-postsecular comes to denote an understanding of the relation of the church to the secular. Modern is equated to secularism, with the syllogistic result that if postmodern follows on modern, post-secular must follow on secular. The question is whether this is a correct assumption which will describe the future relation between the church and the secular. What follows here is a theoretical description of the framework within which this paper is presented. It will be necessary to understand the relevant terminology: paradigm, secular and its derivatives (i.e. secularism, secularisation) as well as related terms (i.e. sacred, profane, religiosity).

\section{Paradigms}

Thomas Kuhn played an important role in describing the impact of paradigms on the development of science. His views were apparently restricted to natural sciences, but have convincingly been applied in social sciences (cf. Bosch 1991:184). According to Kuhn (1962:84), science does not contribute to knowledge in an accumulative fashion. Knowledge originates within a network of contributing factors. A universal frame of mind gives rise to questions and answers. The moment scientists perceive reality to be qualitatively different, an uneasiness regarding traditional answers develops. This anomaly evokes a crisis (Kuhn 1962:82). The scientific model providing answers, or as Kuhn (1962:82) refers to it, a 'paradigm', has become old and tattered and needs to be replaced. New questions demand new answers. This process of replacement is by way of revolution and not evolution. More and more scientists flock to the new scientific theory; model; paradigm as the old one is gradually abandoned. The models may overlap for some time as a discomfort around the old model increases (Kuhn 1962:91). The result is that people respond to the world they live in according to their scientific model; paradigm (Kuhn 1962:110). A new paradigm represents a new worldview (Kuhn 1962:110). When people hold on to different paradigms they are, although living in the same reality, responding to reality as if they live in different worlds (Bosch 1991:184).

A paradigm change brings about progress as new paradigms tend to solve problems better than previous paradigms (Kuhn 1962:152). This however does not mean that progress through new paradigms brings man closer to the truth (Kuhn 1962:169). Evolutionary development as described by Kuhn is not following a modernistic understanding as development toward something. Knowledge develops along a line of what we do not know but wish to know, and not based on that what we know (Kuhn 1962:170). By this Kuhn allays any accusation of modernistic progressive thought. Kuhn (1962:x) defines a paradigm as 'universally recognized scientific achievements that for a time provide model problems and solutions to a community of practitioners.'

Bosch (1991:185) refers to different definitions of paradigm: 'model of interpretation', 'frames of knowledge' and 'frame of reference' and even 'research traditions'. Worldviews as paradigms change over long periods of time. Broad consensus exists that humanity has passed through a pre-modern and a modern paradigm and is currently experiencing what some refer to as a post-modern paradigm. Paradigms influence relationships. Calhoun, Juergensmeyer and Van Antwerpen (2011:6) indicate the historic association between modernisation and secularisation. As modernity spread, secularisation spread, almost as if secularisation can be described as one of the 'pillars of modernity' (Calhoun et al. 2011:6).

\section{The postmodern paradigm}

The emergence of a new paradigm referred to as the postmodern, during the late 20th century, presented challenges to religion (Geaves \& Chryssides 2007:59). A concise description of the postmodern is presented by Geaves and Chryssides (2007:59). The postmodern describes a condition where transformation in society outpaces progress. The pace of transformation creates uncertainty (Geaves \& Chryssides 2007:59), anxiety and doubt (Geaves \& Chryssides 2007:60). The characteristics of postmodern society are heterogeneity, fragmentation and pluralism. There no longer exists only one way of perceiving existence. King (2009:202) describes how the postmodern pursues a sceptical deconstruction of all systems of thought along a 'hermeneutic of suspicion', echoing Ricoeur (King 2009:23). Postmodern thought is suspicious and pessimistic. Religion requires a 'hermeneutic of trust' (King 2009:23), which was prevalent during the Enlightenment (modern period) emphasising certainty, trust and optimism. As to spiritual experiences, postmodern society exchanged the 'disenchanted and demystified world' declared by Weber, for an existence of desire and fantasy (Geaves \& Chryssides 2007:60). The possibility of religion is actually opened up by the postmodern by the questioning of rigid, fixed explanations. As to the claim of truth, the postmodern abandons any security based on a single claim of truth. There are many truths. Certainty failing as truth becomes relational. Pluralism characterises postmodern society (King 2009:202). The change in paradigm brought about the change in the view on secularism. Criticism against modernism entails criticism on secularism (King 2009:202).

King recalls a concise definition of postmodern given by Cupitt: 'Postmodernism is incredulity towards metanarratives' (King 2009:203). King (2009:202) claims that the result of postmodernism is that 'it pursues a sceptical deconstruction of all systems of thought.' The result for religion is that postmodernism does not provide 'the hermeneutics of trust that is necessary for religion' (King 2009:202). Truth and certainty fail when it comes to religion. A plurality of truths emerges. This is according to King not necessarily a threat to Christianity. Postmodernism opens up the possibility for religion (King 2009:216). Religion becomes possible by casting doubt on the grand narratives of modernity and flourishing on the uncertainty of multiple narratives. The importance of reason as the only route to knowledge of human existence is questioned. Postmodernism opens up multiple ways to knowledge by revaluating intuition as a possible way to add to knowledge. 
As has already been indicated the structure of pre-modernmodern-postmodern is emulated in the structure of presecular-secular-post-secular. A short remark on pre-secular is necessary. King (2009:203) characterises the pre-secular as a time of 'monolithic, hierarchical, authoritarian system of thought.' The postmodern is not as much opposed to faith tradition as it opposes faith traditions as structures of power (King 2009:23).

Christianity as reflected on by the discipline of theology exists within a frame of reference. This frame changes over time. At times the frame determined that to be human is to be religious. This might have been true of a pre-secular era. This framework seems to have changed to a situation where the natural state of human existence is to be without religion (Taylor 2007:530). The way in which the secular has been understood over time has been influenced by paradigms.

\section{Secular, secularism and secularisation}

An etymological investigation indicates that the term 'secular' derives from the Latin saeculum (Calhoun et al. 2011:11). The term saeculum originally fell within the temporal domain (Casanova 2011:56), indicating a specific length of time, a millennium: ten saecula. Under Christian interpretation the term saecula came to denote temporary time, the time until the second coming of Christ. The Christian theologian, St Augustine, added an existential dimension by dividing human existence into existence in the City of God, the religious people, and the City of Man, indicating people living in the secular reality to be without the guidance of God. This came to denote those living without Christianity as being secular. References to the secular were no longer only to indicate the temporal but now also the existential.

During the Middle Ages, priests in the Roman Catholic tradition could choose to affiliate with a religious order as opposed to priests who chose to live in the world, thus secular priests not attached to any specific order. Also during the Middle Ages, the word saeculum referred to the process of 'making worldly' as in selling church property (Casanova 2011:56). Where the general understanding of saeculum was temporal, a specific understanding was later added when saeculum became a reference to two distinct worlds, that of the religious, sacred and spiritual as opposed to the secular, profane and temporal (Casanova 2011:56).

The concept of the secular is a mere expansion of the ancient idea by Plato that man ought to engage in higher activities elevated above this (secular) world which is filled with corruption and sin (Calhoun et al. 2011:12). The concept 'secular' thus came to refer to time and place, to the temporal and existential limitations of human existence. Only later did secular come to denote a qualitative differentiation. Opposed to the secular world stands the sacred. This differentiation is also addressed by the separation of transcendence and immanence.

Casanova (2011:55) argues that over time two distinct meanings of the concept of the secular developed. The secular could either refer to a residual category, indicating that which remains when religion disappears from society. On the other hand secular could also refer to a total reality which is seen as the replacement of religion. Religion is then merely an unnecessary addition or superstructure overlaying the secular. These are what Taylor refers to as the 'subtraction stories' (Taylor 2007:29, 531).

The conclusion Casanova (2011:54) arrives at after analysing the term secular, is that it is necessary to separate between secular, secularism and secularisation as these three concepts come to denote different things. The secular is a fairly modern category (Casanova 2011:54) resembling a reconstruction of a reality different than the religious. The secular can function differently in varying contexts and therefore Casanova (2011:54) suggests we talk of 'secularities'. These secularities function parallel to different religiosities and spiritualities (Casanova 2011:54). The category of the secular only recently became a field of research. During earlier periods only the field of the religious was researched (Casanova 2011:54).

What is important is to note that the concept of the secular developed within a Euro-Western-Christian frame of mind. Dobbelaere (2011:611) however indicates that similar examples outside the Euro-Western-Christian context do exist, for instance in the Muslim world (i.e. Turkey and North Africa), where similar processes of secularisation took place. Hans Joas and Klaus Wiegandt (2009) convincingly indicate that secularisation is present amongst all world religions. For some (cf. Casanova 2011) the question as to what the secular is, betrays a Western worldview. Only in Western understanding a differentiation between religion and non-religion is made. In Africa and Eastern worldviews the concept of the secular was apparently not present (Casanova 2011:55) due to the fact that there is no separation made between religion and everyday life. Such a separation between secular and sacred would then in such contexts be unthinkable. Due to the process of globalisation and colonialisation this Western-European understanding of separating the sacred and the secular spread (Casanova 2011:54). This separation is what Dobbelaere refers to as 'compartmentalization' (2011:606).

Casanova's (2011:54) distinction between secular, secularism and secularisation demands an explanation of the related terms. Secularism according to Casanova (2011:54) is a worldview or ideology which takes on many forms, for instance the differentiation between state and religion, between science and philosophy or theology and the differentiation between law and morality (Casanova 2011:55).

The meaning of secularisation is varied. Some refer with secularisation to individual piety as opposed to those who refer with secularisation to the demise of religion in society at large (Dobbelaere 2011:599). Dobbelaere (2011:600) identifies not only a macro or micro level but also a meso level where secularisation has an effect. This leads Dobbelaere (2011) to define secularisation as: 
a process by which overarching and transcendent religious systems of old are confined in modern functionally differentiated societies to a subsystem alongside other subsystems, losing in this process their overarching claims over these other subsystems. (p. 600)

Dobbelaere thus indicates that secularisation refers to the loss of control by religious institutions (like the church) over other subsystems like polity, economy, family, education and law. The relationships between the existing subsystems are changed through the process of secularisation. The effect of secularisation is no longer religious domination over other subsystems, but now being equal or inferior to other subsystems.

Bruce understands secularisation as the process resulting from social and economic influences (1996:26) (also cf. King 2009:31). The social analysis of religion by Durkheim and Weber has contributed to secularisation (Bruce 1996:37). The effect of materialism and production brought about changes in social structures leading to secularisation. For Bruce (1996:32, 2002:3) secularisation exhibits three characteristics: (1) the importance of religious institutions (i.e. the church) in society is on the decline, (2) the social standing of religion is on the decline, and (3) people are less religious. The result Bruce foresees is the gradual decline of religious affiliation leading to a situation where religious people in society are a small minority (in King 2009:31). Bruce does not foresee the reversal of secularisation (in King 2009:32). It is however not clear what the context is which Bruce speaks from. King (2009:32) suggests Bruce's assumptions only apply to the British context.

Secularisation describes a process characterising the modern era (Casanova 2011:54). It refers to the changes made in the relationship between the institutional spheres of the religious and secular. At the base of the process of secularisation is the theory of movement from a primitive sacred to a modern secular (Casanova 2011:54) where religion is seen as a superstructure to be lifted and a return to the secular as the natural order of things is necessary (Casanova 2011:56). In the process of secularisation Casanova (2011:55) indicates that over time two distinct theories developed, namely that religion will decline (with exponents such as Berger, Durkheim and Weber) and that religion will be privatised (exponents such as Luckmann, Berger and Durkheim). This brings Casanova (2011:55) to define secularisation as 'a process of differentiation and liberation of the secular from the religious.' The result is that the secular is seen as superior and prior to the religious (Casanova 2011:56).

Secularisation can be classified into three different categories: '[S]ecularisation as differentiation of the secular spheres from religious institutions, secularisation as decline in religious beliefs and practices, and secularisation as marginalization of religion to a privatized sphere' (Casanova 1994:211). When these three categories are viewed it is clear how some observations of religious activities might be mistakenly labelled as secularisation, when there is in fact a better descriptive term.
The term secularism can refer according to Casanova (2011:66) to two issues: (1) Modern worldviews views and ideologies concerning religion. Secularism becomes an ideology the moment when it entails a theory of what religion is or does. (2) The separation or rearrangement of relationships between state and religion; science and theology; law and morality. The purpose of such separation is to create a neutral, equal and democratic society. Secularism in this instance refers to a state policy relegating religion and politics to separate domains (Casanova 2011:69).

Taylor (2007) is not optimistic about the current state of affairs regarding religion. For him secularisation needs to be understood within the current paradigm. This paradigm Taylor (2007:542-557) puts within what he calls the 'immanent frame'. The immanent frame is constituted by the cosmic, social and moral spheres. All of these are secular and have no immanent transcendence. People live as if God does not exist. This current paradigm describes the current state of affairs. Faith in the transcendence is no longer logic and uncontested. Faith in God has become problematic. Those members of society who still believe, realise their choice to believe is just one choice amongst many, including the choice not to believe. Secularity has become the default option (Casanova 2011:58).

\section{The sacred}

The sacred as opposed to the secular also needs some elucidation. The explanation of religion by Emile Durkheim was a contribution to the understanding of the secular from a Western-European modern perspective. Durkheim ([1912] 2008) based his understanding of religion on the division between the sacred and the profane. The concept of the sacred is a much broader concept than religion or even Christianity. To understand the concept of the sacred it must be seen in opposition to the profane. Man's way of understanding reality is by way of the dichotomy of the division between the sacred and the profane (Pickering 1984:118). This division of the world is a subjective activity originating from man:

The dualism exists in his head. Man has devised it. It comes to the individual from society and is, as it were, turned back on society in order that man may understand it. (p. 118)

Paden (2011:34) however indicates how Durkheim's division between the sacred and the profane would have been better understood had Durkheim stated clearly that the sacred and the profane do not signify 'a class of things', but rather a relationships to things.

This human activity to divide the world along the lines of sacred and profane, Durkheim ([1912] 2008:36) traced back to the dual human nature. Man consists of body and soul (Durkheim [1912] 2008:52). The soul is concerned with that which is sacred and the body is concerned with that which is profane. These two spheres are not divided along qualitative lines as if the one is of higher value than the other (Pickering 1984:119) although this qualitative distinction has easily been made over centuries amongst different religions. Durkheim 
continues to describe human nature along the lines of the duality, by indicating that the profane is associated with all that is individual and the sacred with all that is collective (Pickering 1984:120). The result is that all that is considered sacred results from social activity, and all that is considered profane results from the individual impressions.

Durkheim means by the sacred that which is consecrated or holy (Pickering 1984:126). The sacred refers to that which is set apart, that which society holds in its highest esteem (Pickering 1984:126). For Durkheim that which is considered sacred has a transcendental quality (Pickering 1984:126) and can refer to anything (Durkheim [1912] 2008:36). The profane is that which opposes (Durkheim [1912] 2008:38) and undermines and attempts to destroy the sacred (Pickering 1984:126). These two, sacred and profane, have no contact and remain of separate nature (Durkheim [1912] 2008:39).

Society is seen as the place where the sacred is constructed. For Durkheim all that is considered sacred eventually ends up in a realm (domain or kingdom) of the sacred which ends up as an abstract entity (Pickering 1984:130). The content of this entity differs from society to society (Pickering 1984:130). Society becomes the entity that determines what is sacred and what not (Durkheim [1912] 2008:18). In every society the concept of the sacred exists (Pickering 1984:133).

The distinction Durkheim makes between the sacred and the secular is no longer the only way in which reality can be viewed. Durkheim works with certain fixed assumptions: all in society believe; all in society at some stage have been touched by the transcendental; the sacred exists. Postmodern society would much rather accept a worldview indicating that reality is multifaceted and the sacred and secular are but two components in a much broader whole. To this diversity of religious thought, Taylor attests (2007:531). Durkheim's claim that society determines what is sacred, also no longer applies within a postmodern understanding. As will be indicated later in this paper, the individual plays a much more prominent role in determining what is sacred.

It would however be incorrect to equate the profane with the secular (Casanova 2011:65, 73). Secularisation allows the profanation of religion through privatisation and individualisation. Secularisation also entails the sacralisation of secular spheres such as politics, sciences and economics (Casanova 2011:65). There are instances where the secular state allows religion to be practised. Secular is understood by some as the remainder when religion departs (compare the 'subtraction stories' referred to by Taylor 2007:531). The profane denotes the opposite of religion.

Asad (2003:182) indicates that it is no longer viable to distinguish between the sacred and secular spheres in reality and claims that religion is concerned only with the sacred. According to Asad (2003:182) religion operates in the sacred as well as the secular. Habermas (2010:1) attests to this when he mentions examples of religious symbols and language being transposed into non-religious domains (i.e. religious ideas in films, advertising and theatre). In fact, Habermas (2010:2) believes that religious elements are currently shaping public and cultural life in numerous ways. This refutes Durkheim's distinction between the sacred and profane and the restriction of religion to the private sphere. Asad (2003:30) points out that in pre-modern writing there is no evidence of a separation between sacred and profane. Religion is just as active in the private as the public sphere (Asad 2003:183).

Asad's (2003:30) analysis is that Durkheim and the followers of his line of thought took Robertson Smith's notion of 'taboo' as being the typical form of primitive religion and turned it into the concept of the sacred as a universal essence. The concept of the sacred originated from the research by anthropologists and under the influence of comparative religion developed further and was later on taken over by theologians (Asad 2003:31). The concept of the secular was only introduced after contact with other non-Christian religions (the non-European world) (cf. Asad 2003:32). The secular was then an etiquette to indicate falsity and otherness in comparison to one religion (in this case European Christianity) (Asad 2003:33). The profane was the unmasking of those pretending to be sacred (Asad 2003:33).

Based on the distinction between sacred and secular made by Durkheim, a plethora of related terminology emerged. Secularism, secular, secularity and secularisation can mean different things in different contexts (see Calhoun et al. 2011:5). The meanings range from: reference to temporal existence, to worldliness, to a separation between religion and politics or the more common use, referring to the decline of religion (Calhoun et al. 2011:6).

Gauchet (1997:ix) indicates that secularisation can be defined as (1) the decline of religious belief and practice and the decline in the number of people who declare themselves believers. (2) Secularisation can however also refer to the retreat of religion from the public sphere, causing a neutral identity. Taylor (2007:3) adds a third interpretation by describing a secularised society as a society where the choice for religion has become just another legitimate choice amongst other choices. Society can consist of many religious traditions where the individual can freely choose to affiliate with one tradition (or more or even none!). The society Taylor is describing is not characterised by the decline of religion as the two definitions by Gauchet would suggest.

Taylor (2007:530) indicates the future relationship between sacred and secular has changed due to the change in the frame of reference. The natural order was that of being religious. This has changed due to secularisation. The natural order would now be considered to be secular.

\section{Views on secularisation}

There are not only different definitions for what secularisation is, but also different approaches to understanding it. It is 
presumptuous to proclaim the current era as a time of resacralisation; where re-sacralisation is understood as the process of the reversal of the effect of secularisation. The effect of secularisation should not be ignored. Bruce (2003:261) refers to 'the irreversibility of secularization.' Christianity will still for some time to come have to contend with the secular and the result of the secularisation process.

It appears as if there are four main approaches to understanding the relationship between the sacred and the secular. These factors contribute to an understanding of the future relationship between the secular and Christianity.

\section{Demystification of the world through rationalisation}

One of the first enemies of religion is the human tendency to rationalise. This theory as presented by Max Weber seems to form the core of the traditional theory of secularisation. Rationalisation takes place as intellectual and economic activity.

Weber ([1958] 2003:35, 1966:124) differentiates between different classes in society. One of the strata in society he identifies is the intellectuals. The intellectuals tend to seek meaning in reality through rational ways (Weber 1966:125). This exercise in rationalism suppresses the belief in magic and causes the world to become disenchanted (Weber [1958] 2003:105, 1966:125). Through the process of rationalisation the world is demystified. The mysterious in the world is explained rationally, leaving the world devoid of mystery and secrets. Weber (1966:125) called this the 'world-fleeing intellectualist religion'. Through rationalism there is no more room left for the transcendental to operate in the immanent reality. Every mysterious event now has a logical, rational explanation. All empirical phenomena have a clearly defined meaning. Religion has become obsolete.

According to Weber's ([1958] 2003:40) analysis, the Protestant strand of Christianity seems to be more prone to economic rationalism. Weber suggests that Protestants especially seem to promote rationalism as a means to find prosperity. Wealth and worldly prosperity have been interpreted by Protestant groups to indicate the blessing and grace the God has bestowed upon them (Weber 1966:108, 148). This love for the material and worldly possessions that has been identified with the Protestants will eventually distract attention from religion (Weber [1958] 2003:42) and therefore lead to secularisation (Weber 2003:40). Weber concludes by indicating that Calvinism is the seedbed for capitalistic economy ([1958] 2003:43). Thus, through rationalism and materialism Protestants will bring about secularisation which will lead to the demise of religion. As the process of rationalisation (part of human nature) has not ended and will probably only intensify over time, it is predicted along the line of argumentation Weber presents, that religion will eventually have no place in society and become totally obsolete or that the function of religion in society will constantly change.
Weber is correct in the sense that a world explained rationally has no need of the mysterious workings of God. Where human beings are so in control (economically and politically) there is no need for supernatural assistance and intervention. In a world of material abundance where every commodity is readily available, man has no need of supernatural provision. As to the future of the human soul, a projection of an existence after this life in the superlative luxuries of this world provides comfort. Weber is then correct in assuming that rationality and capitalism made this world devoid of God, stimulating the process of secularisation.

\section{Stadial consciousness}

Unbelief is the condition of modern man. Man has overcome the irrationality of belief. Underlying this statement is the stadial consciousness theory (Casanova 2011:59), describing man's evolutionary development from primitive to modern. Primitive denotes the religious notion of man whilst being modern describes the secular notion of man. Man develops from the stadium of the primitive, irrational, metaphysical religion to the stadium of modern, rational, post-metaphysical secular consciousness (Casanova 2011:58). For Casanova (2011:59) the stadial consciousness theory contributed the most to secularisation. In societies where the stadial consciousness is absent, secularisation also seems to be absent, although religious revival seems strong in such communities.

Part of the stadial consciousness theory is that religion is seen as being intolerant and quite often responsible for creating conflict (Casanova 2011:69). In this discourse the reference is quite often to the religion of others or the religion someone decided to leave behind. To be secular then presents a condition where one is free from religion, thus free from intolerance. To be secular thus means to be tolerant.

Durkheim, after analysing the social order of his time, came to the conclusion that religion is on the decline or in regression (Pickering 1984:442). This was not only true of traditional religion but also Christianity proved to be dying according to Durkheim (Pickering 1984:442).

For Durkheim the organic nature of religion enabled religion to be born, to grow and eventually die. This process was inevitable as endless. Durkheim's understanding of what is now referred to as secularisation falls into two separate headings: the changing of religion altogether and the change or decline of religion within society (Pickering 1984:442). On the latter issue Durkheim acknowledged the process of religion dying but simultaneously acknowledging the perseverance of religion. This reflects Durkheim's description of the situation in his own time but also his understanding of the normative role of religion.

The implication of Durkheim's theory is that the more primitive a society is the more influence religion has on society (Pickering 1984:443). The opposite of course being that the less influence religion has on society the more 
modern society has become. This is one of the peculiarities of Durkheim, suggesting a society becomes more religious when it regresses to its original form. For Durkheim regression would then be positive as it denotes a return to religious dominance in society.

The decline of religious influence in society is for Durkheim not something new (Pickering 1984:445). Since the first communities with religious dominance man has slowly been evolving into societies where religion plays a lesser role. This contention is opposed by Robert Bellah's theory (2011) that religion does change by way of evolution. Change does not eradicate religion, but rather results in different forms or functions of religion in society. Durkheim proclaimed that religion will play a diminishing role in social life (Pickering 1984:446). As time passes social institutions like politics, economy and science will free themselves from religion, growing into a situation of increasing individual freedom (Pickering 1984:446).

\section{Subtraction theory}

Secularity is what remains when religion is removed from society. The secular is seen as the substratum which remains the moment when religion as superstructure is removed (Taylor 2007:530). For Taylor (2007:269) the modern unbelief does however not equal the absence of belief or even equals indifference.

For Berger (1969:107) secularisation refers to the process by which sectors of society and culture are removed from the domination of religious institutions and symbols.' Berger's theory makes more sense in the light of Durkheim's distinction ([1912] 2008:36) between the sacred and the profane which characterises the world in which humans exist. The purpose of Berger's analysis was to evaluate the way in which society understands its own position in the world, the worldview and the position of humanity as seen not from a religious perspective. Durkheim's distinction, namely the strict separation between the sacred and profane, is disappearing. For some members of society some elements might still be considered to belong to the profane as for other members of society the same elements might be considered to belong to the sacred.

The description by Berger makes the subjective and objective side of secularism clear. Berger (1969:15) professed that the objective side of secularisation would be carried by the loss of organised religion's influence. The influence of religion on the public domain would become less visible. Arts, philosophy and even literature would exhibit less influence by religion. Sundermeier (1999:12) describes a society where the religious influence on social institutions like marriage and education has disappeared. Knowledge of religious symbols has dissipated. On the other hand a subjective side to secularisation is to be noted (Berger 1969:15, 16). Individuals in society no longer exhibit the need for the concept of the transcendental. The understanding of the world, humanity and ethics are no longer determined by religion. People affiliate less with formal religious institutions but rather fall back on a subjective constructed universe filled with selected religious elements.

This is what Berger refers to as the 'privatisation of religion' (Berger 1969:133). Religion is no longer a public matter, but a personal matter. Sundermeier (1999:12) confirms this by indicating how this emphasis on the profane instead of the sacred, does not mean the end of religion. The growth of new religious movements and the resurgence of fundamentalism and esotericism merely prove that religion seeks new ways of expression; no longer expression in an institutional way but in a private manner (Sundermeier 1999:13).

\section{Disappearance thesis}

The disappearance theory is based on tendencies of decline of religious activities and participation in religious communities, resulting in religion dying out. Steve Bruce is an exponent of this view. For Bruce $(1996: 5,230)$ the Protestant Reformation was the starting point of the large scale eradication of religion. The Reformation, according to Bruce, contributed to individualism. The Reformation eroded rationalism. To believe in something is different than being convinced it is true (Bruce 1996:230).

For Bruce (1996:233) religion becomes an individual matter. Religion has become a subjective, selective, 'pick-and-mix' of elements which the individual prefers. The social relevance of religion is on the decline and will eventually disappear (Bruce 1996:133). For Bruce Christianity exhibits a clear line of gradual regression from congregation to denomination leading to cult and eventual irrelevance. This effect of secularisation will remain permanent (Bruce 2003:262).

Taylor (2007:542) explains the disappearance of religion as due to the change of frame. The 'immanent frame' (Taylor 2007:542) within which modern man exists, does not make provision for the existence of the transcendental. The existence of God is no longer part of the frame of reference for postmodern man. All meaning is retained in an immanent world, causing reality to be devoid of higher values and meaning. God has disappeared. Berger (1969) referred to the sacred canopy that no longer functions like it was intended. Due to this view religion cannot but die out and disappear.

These four elements can be viewed as the different perspectives contributing to secularisation.

\section{Sacralisation}

In spite of the reality of the process of secularisation and the effect it had on the church, the church has not disappeared. Christianity is still alive and well today.

In spite of Durkheim's negative evaluation of the regression of religion in a European context, he still remains positive about the future of religion. He is strongly convinced that religion will continue to exist (Pickering 1984:452). For Durkheim it is not so much the disappearance of religion that is at stake 
but the changing of religion. The old will pass - the new will be born (Pickering 1984:453). This reflects the understanding by Durkheim that the changing of society includes religious change. Religion changes as the society of which it is part, changes (Pickering 1984:453).

Durkheim is convinced that religion will persist. The old religion might die out, but the new religion will be born. This creative process is part of society and human nature (Pickering 1984:476). As long as man lives together in community man will continue to have religion. This, Durkheim predicts enthusiastically and with certainty. The form the future religion will take on he is not willing to predict (Pickering 1984:476). Weber is however not so convinced about the future existence of religion. Casanova (1994:18) summarises Durkheim's and Weber's work by indicating that their diagnosis was similar but that they did not share the same prognosis of the future of religion.

The term sacralisation refers to a reverse process. When secularisation refers to a process to empty the world of religious character, the process of sacralisation intends to re-inhabit the world with religion; to restore the sacred; to mystify the world again (compare Weber's contention that the world is being de-mystified through modernisation and rationalisation). The process of sacralisation is a conscious, arbitrary, subjective process of re-introducing a plurality of religious elements into society.

Where Berger was initially quite negative about the persistence of religion, he is convinced that religion will not only persist, but will grow: 'The world today is massively religious, is anything but the secularized world that had been predicted' (Berger 1999:9). The old secularisation theory might be true in some instances, but in general, Berger (1999:12) finds the theory that 'secularity will triumph', unpersuasive.

Berger analyses two separate contexts and comes to the conclusion that what has previously been branded as secularisation is in fact not. The 'massively secular Euroculture' Berger determines, exhibits what he would rather call the 'widespread alienation from the organized church' or 'a shift in the institutional location of religion' (Berger 1999:10). This is a much more accurate description of the situation in Europe. This corresponds to what Weber and Durkheim described as changes in society that will bring about changes in religious behaviour. On the American context, Berger (1999:10) remarks that 'Americans are much more religious as well as more churchly than Europeans'.

It is clear to Berger that the current European society did not discard Christianity completely, but that it would be more accurate to describe a change in the form of Christianity than depicting the situation as secularised. Berger (1999:10) admits that there is indeed an 'international subculture composed of people with Western-type higher education' that he would regard as secularised. In spite of this secularised grouping in society, Berger (1999:11) identifies an international religious upsurge. The character of this upsurge is twofold: religiously motivated but also protesting 'against a secular elite' (Berger 1999:11).
As to the reasons for the unexpected upsurge in religion, Berger provides three reasons:

- Certainty against uncertainty (1999:11): Where any paradigm undermines certainties man experiences in society, a discomfort is created and the seedbed for religious upsurge is prepared. When any religious movement steps into society promising certainty, society will immediately grasp the opportunity to regain certainty.

- Resisting and opposing the secularised elite in society (1999:11): When a section of society promotes a secular view of reality threatening the beliefs and values of society, the majority of society will reject this view and follow religious movements which proclaim anti-secular sentiments.

- Human nature (1999:13): It is part of human nature to find meaning outside of this empirical world. The search for meaning is more severe in cultures that have been without any 'transcendent point of reference'.

The very nature of man contributes to the survival and persistence of religion. Berger's (1999) definition of religion illustrates this:

It is part of human nature to search for meaning that transcends the restricted space of empirical existence in this world. When this search for meaning is halted by way of secularisation, human condition will be without transcendence. This will leave man impoverished in an untenable condition. (p. 13)

This 'untenable condition' of meaninglessness motivates man to continue the search for meaning, bringing about the perseverance of religion. The form religion takes on might change due to society that changes. In this regard Berger shares Durkheim's position that the future religion will take on a different form: religion becoming a personal matter (cf. Pickering 1984:447).

Following Durkheim's line of argumentation, Thomas Luckmann holds the theory that religion, instead of dying out in society, will end up in an invisible form; religion is still a dimension of existence of the individual and society, 'but is empty of specific empirical content' (Luckmann 1967:78). In line with Durkheim and Berger, Luckmann (1967:86) suspects that religion will disappear from the public eye and become 'a private affair'. This is based on one of the consequences of modernity and rationalisation, putting the individual at the centre, forcing the individual to find ways of self-expression separate from a collective identity (Luckmann 1967:70, 76). What in fact happened according to Luckmann is not necessarily the disappearance of religion as the change in form religion underwent.

\section{The church and the secular}

The effect of secularisation and even post-secularity on Christianity cannot be denied or ignored. It might be premature to predict the end of secularisation. It is however clear that a change in paradigm has taken place. Under a postmodern paradigm the relationship of the secular and 
Christianity will change. How then should the effect of the post-secular era on the church be viewed? Will Christianity disappear or will it change? Is it only the function of the church that is prone to change or will Christianity all together change? What will the issues theologians in future will have to contend with be? I suggest that the effect of the post-secular on Christianity can be described along four lines: individualisation, fragmentation, fundamentalism and civil religion.

\section{Individualisation}

The differentiation of secularisation into macro, meso and micro levels suggests that secularisation also affects the individual. With individual secularisation, Dobbelaere (2011:606) refers to the situation where religious authorities have lost control over the beliefs, practices and moral principles of the individual. This however does not imply a decline in religion but rather a change in localisation. Religious authority no longer rests with the church. The individual now has the ability and will to autonomously decide what to believe. This notion has already been picked up by Luckmann (1967) when he referred to the invisible form of religion. With this Luckmann meant to indicate how religion will disappear from the public eye and only function within the private sphere. Religion becomes an activity of the individual. Durkheim indicated how society will determine what is sacred. Under a changed paradigm society no longer has that role. The individual decides what is sacred. This however does not necessarily mean a change in confessional faith, but the emphasis on confessional elements might differ from individual to individual.

Dobbelaere (2011:607) indicates the implications of individualisation. Practicing religion becomes a subjective and private matter. The individual selectively decides what elements of religion are desirable and functional, creating a 'religious bricolage' or 'pick and choose religiosity' (Dobbelaere 2011:606). Note that Dobbelaere uses the term 'religiosity', 'spirituality' or 'religiousness' for this new phenomenon (cf. Taylor 2007:535). There can no longer be talk of religion when referring to institutionalised religion. For the individual, flexible, non-dogmatic experiences are now of importance (Dobbelaere 2011:606). Personal spirituality now exhibits a mixture of heterogeneous religious elements, selected subjectively. Taylor (2007:534) attests to this when he refers to it as 'minimal religion', namely spirituality practiced by the individual within one's own immediate circle of friends and family. This form of religion originates outside the confessional structures. Of this the growth of house churches is an indication. Small groups of individuals break with the institutional church and form new 'informal' faith communities, emphasising specific elements.

In the current pluralist world man is exposed to different religions and even the absence thereof. The continuation of belief, according to Taylor (2007:531), now rests upon the intuition of the individual. The individual needs to make a choice. To choose for religion is a choice amongst many other possible choices (Taylor 2007:531). The availability of a variety of religious options is not a threat to Christianity, but rather a stimulus for the growth of religion. Bruce (1996:212) states the opposite by indicating how individualistic subjectivity hastens the end of religion.

We can no longer talk about religion as the communal response to and experience of the transcendental as expressed in ethics and rituals (cf. Sundermeier 1999:17). A more appropriate and context-sensitive definition of religion is necessary. My suggestion of a revised definition of religion in a post-secular era might be the following: religion is a subjective and temporary selection of religious elements contributing to meaning in the life of the individual.

Emphasising the subjective nature of religion, Christianity can no longer be viewed as a communal response. The individual determines what elements constitute Christianity. Along with the subjectivity comes the element of temporality. Elements subjectively selected can be exchanged from time to time. Elements can drift in and out of the sphere of the sacred. The elements constituting Christianity are arbitrary building blocks varying from rituals, doctrines and traditions selected from a wide variety of options (cf. Taylor's [2007] description of the multiple choices associated with the postsecular era). As Berger (1999:13) indicates, religion is human nature pressing to find meaning. Meaning refers to a higher value than mere (temporal and profane) existence. This meaning can be described as the transcendental. Human existence is not limited to an earthly life limited in space and time. Human existence extends across the border of this worldly existence.

Within a new (postmodern) paradigm, the ways in which knowledge is gained increase. Rationality is no longer the only way of finding meaning. The individual can now also rely on the emotional and experiential as sources for religious knowledge. The authority of the institutional church over doctrine disappears and is replaced by subjective, individual choices of doctrine. This in turn might lead to what I prefer to call 'relative Christianity'. The form and function the church takes on as expression of Christianity, are relative to the need and wisdom of the individuals involved in a local setting. Christianity might be perceived to grow, but in fact it might only be a change of location: the institutional church is growing smaller, but informal Christian communities are increasing.

There might even be a different scenario as to the function of rationality. Rationalisation plays an important role in individualisation. The Enlightenment period which emphasised rationality led to a differentiation between reason and opinion, indicating that which reason cannot accommodate. Religion had become irrational, relegated to the world outside of reason. Reason replaced clerical authority with reasonal forms (Joas 2008:109).

The effect of the Enlightenment has already been discussed above with Weber's ([1958] 2003:105) famous declaration 
of the 'demystified world'. The effect on religion was that religion was seen as a discipline where reason plays no role. The struggle between reason and religion continued throughout the modern era. Habermas (2010:23) indicates how a post-secular era now reintroduces the importance of reason within the discussion of religion. The argument is merely that if the modern era emphasised rationality, causing religion to fall outside of the scope of rationality, the postmodern will again introduce rationality to religion. Joas (2008:105) indicates how Habermas identifies the ongoing conversation between religion and the rational (secular) reality.

Rationalisation can be seen as a form of individualisation. Reason and religion were inequitable during the modern era. If rationalisation characterised the modern secular era, Habermas (2010) suggests that in a post-secular era reason will again be part of religion. The effect of the post-secular era on Christianity will, for Habermas, entail a reintroduction of reason to faith. Christianity will again utilise reason.

This statement needs to be carefully scrutinised as the universal application is under suspicion. Christianity will not denounce its mysterious, irrational (note: not unrational) character. Many religions do not wish the rational explanations and analysis of myths, rituals and dogmas. Rational influence is still perceived by some as a step towards secularisation.

\section{Fragmentation}

Secularisation, as has been indicated earlier, is the process which amongst other elements refers to the separation of spheres. Christianity has become detached from the spheres of politics, education, economics, judiciary and science. Different spheres end up in separate compartments. Dobbelaere (2011:606) refers to this process as 'compartmentalization'. The question Dobbelaere (2011:606) addresses is whether during a post-secular era the restoration or integration of spheres becomes necessary or functional? Should the systems be understood as separate and autonomous with Christianity being denied any influence in any sector (Dobbelaere 2011:606)? Dobbelaere (2011:607) indicates the result of research done on these questions. The more a person has a religious commitment, the less the objection against religion influencing other sectors. People with no or a lesser degree of religious commitment, object more to religion influencing other sectors. The result is that religious people are prone to promote the influence of religion in other sectors. In a South African context where the majority of the population indicates some religious affiliation, religion is still permitted access to different spheres of existence. Compare the relative tolerance of religious activities at schools, religious leaders officiating at public events and symbolic gestures made in public by sportsmen and sportswomen. The tolerance of the presence of Christianity in public spheres has to be understood in a South African context from the perspective of freedom of religious affiliation and freedom of speech encapsulated in the Constitution.
Compartmentalisation is a social matter. Society will determine if Christianity be permitted access to all spheres of life. I suspect access will only be granted based on functional reasons. If religion plays a functional role in other spheres, access might be considered. Access will not be granted automatically. Compare in this regard Asad's (2003:182) and Habermas' (2010:1) remarks indicating the presence and influence of religion on different sectors of life. Habermas (2010:2) believes that religious elements are currently shaping public and cultural life in numerous ways. Religion can play a role in creating identity and unity. Religion can even be expression of an already existing identity and unity.

It might also in this case be presumptuous to announce the return of religion to the public sphere. Every context must be taken into consideration. Every example of suspicion that religion influences different sectors of life must be carefully scrutinised. I suspect that in many cases the influence is not based only on religious convictions but also based on ideological grounds. Religion as identity marker causes people to reaffirm their presence in society by way of religious influences on matters such as economy, judicial and political matters.

Opposite to compartmentalisation stands integration. In a pluralist society integration of spheres is a post-secular phenomenon. Religion can become part of other areas in life: sociology, psychology, health and worldviews. Religion no longer stands as superior above other areas in life, neither besides, but can now be integrated into other areas. This results in an invisible religion. Religion is so integrated into other spheres that no distinct sign of religion is visible any more. Institutionalised religion might be on the decline but is replaced with religiosity. Morals and values in society might create the illusion of the presence of religion, but might only be the remnant of collective (cultural) ethics.

\section{Fundamentalism and civil religion}

For Taylor (2007:530) one of the characteristics of a pre-modern world is the integration of religion into society, to such an extent that social life had become impossible without religion. Social existence was viewed on a continuum as civility equals Christianity equals order. The introduction of other religions made Christianity a default, no longer acceptable, resulting in compartmentalisation, or 'fragilization' as referred to by Taylor (2007:531). The multiplicity of options is the way in which Taylor (2007:531) describes secularisation. There are however societies that still hold on to Christianity as the default position (Taylor 2007:531) as opposed to societies where the default position is unbelief.

The reaction to pluralism in society is varied. One possibility is that pluralism results in relativism, contributing to the decline of religion. A different possibility is that plurality creates a competitive market situation which contributes to the growth of religion (compare the discussion on this matter by Bruce 1992:171). The growth of religion can result in institutionalised growth or in what Bruce (1992:189) refers 
to as 'sub-culture formation'. This subculture can refer to enclaves of religiosity in society based on the restoration of the past. These pockets of religion as default position in society can take on the form of fundamentalism or civil religion.

Civil religion refers to the instance where conversion to a religion is ethnically based. The spread of a religion is along the lines of language and culture (Bruce 1996:96), resulting quite often in what Bruce (1996:96) calls 'nominal conversion'. To belong to a particular culture implies belonging to a particular belief. The religion then becomes the guardian and defender of ethnic identity. Civil religion becomes a remnant of a society trying to restore the conditions and connections of a previous era where religion played an important role in decisions in society. When under threat of secularisation, a society can either adapt to the new condition or retract to the familiar situation of the past. Civil religion is an example of the latter.

Johnstone ([1975] 2004:153) adds a different perspective to the understanding of civil religion by indicating that a section of society interprets the foundation of their society and its progress through history as being part of a larger, divine plan. Society as a structure has a transcendental dimension. Being part of the nation elected by God provides identity and a sense of belonging. Religion is integrated in social life. Johnstone indicates how Williams (in Johnstone [1975] 2004:154) refers to this as 'societal religion' where religion has the social function of maintaining the democratic nature of society and integrating members of society into a whole.

Some Christian communities in South Africa might still have this self-understanding of being godly elected. Their presence in Africa is part of a divine plan of not only Christianising Africa but also civilising a dark continent. Such ideas, although prevalent, are only present amongst a minority few.

Fundamentalism is closely related to civil religion, in the sense that fundamentalism is a reaction to the threat of any change, which might include secularisation (cf. Johnstone [1975] 2004:164). Wentzel (2011:179) identifies fundamentalism as a reaction to the spiritual emptiness of modernity and the relativism of postmodernism. These unfavourable conditions during the modern and postmodern era led to a resurgence of religiosity. It is however important not to confuse fundamentalism with the postmodern. Wentzel (2011:180) indicates that fundamentalism much rather reflects a premodern situation where the authority and truth of religion is maintained. Fundamentalism plays an important role in reinforcing morals and ethics in traditional communities. In this way fundamentalism supports civil religion.

The struggle in which fundamentalism engages is not only directed at the 'external enemy' of religion but also at the 'internal relativism' within religion. Within a religious community institutional and doctrinal authorities are emphasised (Wentzel 2011:181). In this sense fundamentalism makes the distressing pressure of choices in a multi-religious world (cf. Taylor 2007) easy by providing the fixed and 'only' answer ready at hand for those seeking certainty (cf. Krüger's analysis of fundamentalism [2006]). Wentzel (2011:181) suggests that an instance where religion in a postmodern context is growing is mostly fundamentalistic. Bruce (1996:152) confirms this by indicating the role fundamentalism plays in restoring traditional values in societies. This endeavour of fundamentals should not be demonised.

The ugly face of fundamentalism is when Christian communities try to restore the 'good old days' when certainty was institutionally ensured. No deviation of church doctrine was possible or tolerated. Krüger (2006:892) emphasises how change and alternatives become threats to Christian communities. Fundamentalism is the effort to restore and maintain an order that existed in the past. All change of the past order is perceived as evil and regressive. No opposition is tolerated in fundamentalistic circles (Krüger 2006:893, 897). One is either together with us or against us. No alternative interpretations are permitted. There is only one understanding and interpretation of scripture. Krüger (2006:898, 903) indicates that fundamentalism should be understood as a way of practising hermeneutics.

In a South African context, Christianity might splinter off into smaller communities, either in the form of house churches, or fundamentalistic groups. This might create the impression that Christianity is multiplying. In effect it is merely the result of decentralisation, that means a scattering of Christian communities. Besides this, the devastating effect of secularisation should not be ignored. Krüger, Lubbe and Steyn (2005:303) indicate how some sections of society respond to secularisation with atheism. Many Christians feel 'relieved' from the burden Christianity might have put upon them. Now, when able to make a choice, many choose not to believe in anything.

\section{Conclusion}

Christianity may in a post-secular context continue to exist. The growth experienced by Christianity in a South African context can either be in the form of individual religiosity or civil religion or fundamentalist forms. The effect of the post-secular on religion can be summarised by referring to the social effect of individualisation and fragmentation. Furthermore, Christianity can take on the form of civil religion with the function of guarding ethnicity and fundamentalism - guarding morals in society. This will be the form of Christianity with which theologians in future will need to contend. Whereas the first two sections in the relationship of the church with the secular dealt with 'Individualisation' and 'Fragmentation', the last section suggests the opposite effect of the post-secular on Christianity, namely that of integration of society, no longer emphasising the fragmentation and alienation of the individual. This should however not be disturbing as diversity characterises postmodernity. No one uniform response to the post-secular can be expected. 


\section{Acknowledgements}

\section{Competing interests}

The author declares that he has no financial or personal relationship(s) that may have inappropriately influenced him in writing this article.

\section{References}

Asad, T., 2003, Formations of the secular: Christianity, Islam, Modernity, Stanford University Press, Stanford.

Bellah, R., 2011, Religion in human evolution: From the Palaeolithic to the Axial Age, Harvard University Press, London. http://dx.doi.org/10.4159/ harvard.9780674063099

Berger, P.L., 1969, The sacred canopy: Elements of a sociological theory of religion, Anchor Books, New York.

Berger, P.L., 1999, 'The desecularization of the world', in P.L. Berger (ed.), The desecularization of the world: Resurgent religion and world politics, pp. 1-18, WB Eerdmans, Grand Rapids.

Bosch, D.J., 1991, Transforming mission: Paradigm shifts in theology of mission, Orbis Books, New York.

Bruce, S. (ed.), 1992, Religion and modernization: Sociologists and historians debate the secularization thesis, Clarendon Press, Oxford.

Bruce, S., 1996, Religion in the modern world: From cathedrals to cults, Oxford University Press, Oxford.

Bruce, S., 2002, God is dead: Secularization in the West, Blackwell Publishers, Oxford. Bruce, S., 2003, 'The social process of secularization', in R.K. Fenn, (ed.), The Blackwell companion to sociology of religion, pp. 249-263, Blackwell Publishing, Oxford.

Bruce, S., 2008, Fundamentalism, Polity Press, Cambridge.

Calhoun, C., Juergensmeyer, M. \& Van Antwerpen, J., 2011, Rethinking secularism, Oxford University Press, Oxford.

Casanova, J., 1994, Public religions in the modern world, University of Chicago Press, Chigago.

Casanova, J., 2011, 'The secular, secularizations, secularisms', in C. Calhoun, M. Juergensmeyer \& J. van Antwerpen (eds.), Rethinking secularism, pp. 54-74, Oxford University Press, Oxford.

Dobbelaere, K., 2011, 'The meaning and scope of secularization', in P.B. Clarke (ed.), The Oxford handbook of the sociology of religion, pp. 599-615, Oxford University Press, Oxford.
Durkheim, E., [1912] 2008, The Elementary forms of religious life, transl. C. Cosman Oxford University Press, Oxford.

Gauchet, M., 1997, The disenchantment of the world: A political history of religion, Princeton University Press, Princeton.

Geaves, R. \& Chryssides, G.D., 2007, The study of religion: An introduction to key ideas and methods, Continuum Books, London.

Habermas, J., 2010, An awareness of what is missing: Faith and reason in a postsecular age, transl. C. Cronin, Polity Press, Cambridge.

Joas, H., 2008, Do we need Religion? On the experience of self-transcendence, Paradigm Publishers, London.

Joas, H. \& Wiegandt, K. (eds.), 2009, Secularization and world religions, Liverpoo University Press, Liverpool. http://dx.doi.org/10.5949/UPO9781846315671

Johnstone, R.L., [1975] 2004, Religion in society: A sociology of religion, 7th edn., Pearson Education, New Jersey.

King, M., 2009, Postsecularism: The hidden challenge of extremism, James Clark \& Co, Cambridge.

Kuhn, T.S., 1962, The structure of scientific revolutions, The University of Chicago Press, Chicago.

Krüger, J.S., 2006, 'Religious fundamentalism: Aspects of a comparative framework of understanding', Verbum et Ecclesia 27(3), 886-907.

Krüger, J.S., Lubbe, G.J.A. \& Steyn, H.C, 2005, The human search for meaning. A multireligious introduction to the religions of humankind, Via Afrika, Pretoria.

Luckmann, T., 1967, The invisible religion: The problem of religion in modern society, MacMillan, New York.

Norris, P. \& Inglehart, R., 2004, Sacred and secular: Religion and politics worldwide, Cambridge University Press, Cambridge. http://dx.doi.org/10.1017/ CB09780511791017

Paden, W.E., 2011, 'Reappraising Durkheim for the study and teaching of religion', in P.B. Clarke (ed.), The Oxford handbook of the sociology of religion, pp. 31-47, Oxford University Press, Oxford.

Pickering, W.S.F., 1984, Durkheim's sociology of religion: Themes and theories, Routledge \& Kegan Paul, London.

Sundermeier, T., 1999, Was ist religion: Religionswissenschaft im theologischen Kontext, Kaiser Verlag, Gütersloh.

Taylor, C., 2007, A secular age, Harvard University Press, Cambridge.

Weber, M., [1958] 2003, The Protestant ethic and the spirit of capitalism, transl. T. Parsons, Charles Scribner's Sons, New York.

Weber, M., 1966, The sociology of religion, transl. E. Fischoff, Methuen and Co. London.

Wentzel, N.G., 2011, 'Postmodernism and religion', in P.B. Clarke (ed.), The Oxford handbook of the sociology of religion, pp. 172-193, Oxford University Press, Oxford. 